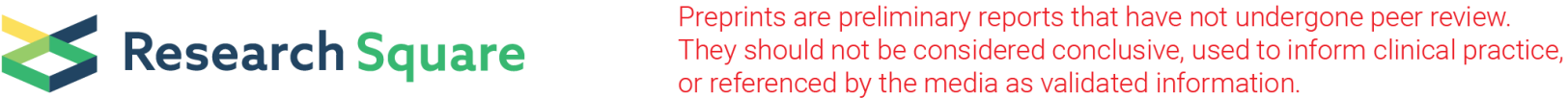

\section{Development of A LC-MS/MS Method for Simultaneously Determining Nucleosides and Methy-Nucleosides in Mice Liver mRNA of Epimedin C-Induced Liver Injury Model}

\section{Zhizhen Song}

First Affiliated Hospital of Zhengzhou University https://orcid.org/0000-0003-4043-608X

\section{Zeyun Li}

The First Affiliated Hospital of Zhengzhou Hospital

\section{Xueqian Wen}

The First Affiliated Hospital of Zhengzhou Hospital

Ruijuan Liu

The First Affiliated Hospital of Zhengzhou Hospital

Xin Tian ( $\square$ tianx@zzu.edu.cn )

First Affiliated Hospital of Zhengzhou University https://orcid.org/0000-0003-0392-6362

\section{Research}

Keywords: LC-MS/MS, Epimedin C, liver injury, nucleosides, mRNA methylation

Posted Date: June 24th, 2021

DOI: https://doi.org/10.21203/rs.3.rs-612580/v1

License: (a) This work is licensed under a Creative Commons Attribution 4.0 International License. Read Full License 


\section{Abstract \\ Background}

Epimedium, the crude drug used in clinical, has been proved to have the potential to cause liver damage in patients. As one of the main active ingredient of Epimedium, Epimedin $\mathrm{C}$ is reported to have the potential hepatotoxicity. However, the mechanism of Epimedin C-induced mice liver injury has not been studied. mRNA methylation is implicated in the regulation of many biological processes and diseases. The study of mRNA methylation in Epimedin C-induced liver injury may contribute to clarify the liver toxicity mechanism of Epimedin C. Therefore, an analysis method needs to be established to determine liver mRNA nucleoside and methy-nucleoside levels in epigenetic studies.

\section{Methods}

The Epimedin C groups were intragastrically administered single doses of 10 and $40 \mathrm{mg} / \mathrm{kg}$ body weight of Epimedin $\mathrm{C}$ for four weeks, and the normal control group were given the same volume of saline. The results of hematoxylin and eosin staining of the liver and serum aminotransferase levels were used to evaluate liver injury. The nucleoside samples of the mice liver mRNA were prepared and separated on an UPLC column using $0.1 \%$ formic acid water and methanol after enzymatic digestion. Then the sample was detected by a Qtrap 6500 mass spectrometer.

\section{Results}

In this study, a selective, rapid and sensitive method was established using high performance liquid chromatography-tandem mass spectrometry for the simultaneous determination of six nucleosides (adenosine, uridine, cytidine, guanosine, N6methyladenosine and N5-methylcytidine) in mRNA. In this method, linear concentrations of adenosine, cytidine, N6methyladenosine and N5-methylcytidine were $40-20000 \mathrm{pg} / \mathrm{mL}$, guanosine was $0.2-100 \mathrm{ng} / \mathrm{mL}$, and uridine was $2-1000$ $\mathrm{ng} / \mathrm{mL}$. N6-methyladenosine and N5-methylcytidine modification levels of the mice liver mRNA increased after Epimedin C treatment. Epimedin $\mathrm{C}$ led to the elevation of serum aminotransferase levels, and increased the inflammatory cell infiltration and vacuolar degeneration in liver, indicated the liver injury in mice.

\section{Conclusion}

This method was successfully applied to the detection of six liver mRNA nucleosides levels in Epimedin C-induced liver injury with good precision and accuracy. The results indicated that mRNA methylation might be associated with Epimedin Cinduced liver injury. This study offers a method for the research on the mechanism of Epimedin C-induced liver injury, and will facilitate the research on the hepatotoxicity of herbal medicine in epigenetic studies.

\section{Background}

In recent years, the incidence of drug-induced liver injury has been increasing year by year due to the surging demand for herbal medicine and health care products[1]. Epimedium, the crude drug used in clinical, is the dry leaf of Epimedium brevicornum Maxim., Epimedium sagittatum (Sieb.et Zucc.) Maxim., Epimedium pubescens Maxim., and Epimedium koreanum Nakai. Epimedium preparation is widely used for rheumatism, arthritis, osteoporosis and other diseases in China[2-3]. However, herbal preparations containing Epimedium have been reported to have the potential to cause liver damage in patients[4-5]. As one of the main active ingredient and quality indicator of Epimedium, Epimedin $\mathrm{C}$ is metabolized to 2"-O-rhamnosylicariside $\mathbb{~ i n ~ t h e ~ b o d y , ~ w h i c h ~ h a s ~ s t r o n g ~ c y t o t o x i c i t y ~ t o ~ H L - 7 7 0 2 ~ a n d ~ H e p G 2 ~ c e l l s [ 6 - 8 ] . ~ D e s p i t e ~ s o m e ~}$ reports to the potential hepatotoxicity, the mechanism of Epimedin C-induced liver injury has not been studied. 
Methylation modification of messenger RNAs (mRNA), as an important RNA modification in mRNA, has been widely proved to effect on a variety of biological processes and related diseases, including metabolism, circadian rhythm, immune response, gametogenesis, neurologic development, and cancer[9-11]. At present, the methylation modifications of mRNA have been found mainly include N6-methyladenosine (m6A), N5-methylcytidine (m5C), N1-methyladenosine (m1A), N7methylguanosine $(\mathrm{m} 7 \mathrm{G})$, and so on. A large number of studies have shown that methylation modification disorders of mRNA are closely related to the occurrence and development of a variety of diseases. Studies indicated that m6 $\mathrm{A}$ is associated with the progression and metastasis of hepatocellular carcinoma[12-13]. Alteration of $m 5 C$ in Neurons may lead to cell stress response and apoptosis[14]. The level of $\mathrm{m} 5 \mathrm{C}$ modification is closely related to PI3K/Akt signaling pathway in gastrointestinal malignancies[15]. However, the relationship between mRNA methylation and Epimedin C-induced liver injury is still unknown. m6A and $\mathrm{m} 5 \mathrm{C}$ are the dominant modifications in mRNA methylation in vivo. The study of m6A and $\mathrm{m} 5 \mathrm{C}$ in Epimedin C-induced liver injury may contribute to clarify the liver toxicity mechanism of Epimedin C. In consequence, the content of mRNA methylation in Epimedin C-induced liver injury should be quantified.

Although some studies described the detection method of m6A and m5C in total RNA and DNA, the method for the simultaneous quantification of six nucleosides (adenosine, uridine, cytidine, guanosine, m6A and m5C) in mRNA was less reported[16-22]. Because of the fewer levels of m6A and $\mathrm{m} 5 \mathrm{C}$ in mRNA than total RNA, new method should be established to enhance the detection sensitivity. A reliable method to simultaneous determination of $\mathrm{m} 6 \mathrm{~A}$ and $\mathrm{m} 5 \mathrm{C}$ could contribute to the epigenetic research of hepatotoxicity or other complex diseases.

In this study, a selective, rapid and sensitive method was developed using high performance liquid chromatography-tandem mass spectrometry to simultaneous determination of six nucleosides (adenosine, uridine, cytidine, guanosine, m6A and m5C) in mice liver mRNA in Epimedin C-induced liver injury model. It might provide new idea for further research on the mechanism of herbal medicine-induced liver injury.

\section{Materials And Methods}

\section{Chemicals and reagents}

Epimedin C (purity $\geq 98 \%$ ), used as the dosage administration, was purchased from Cdmust Biology Technology Ltd. (Chengdu, China). Lamivudine (internal standard, IS, purity $>98 \%$ ), adenosine (purity $>99 \%$ ), guanosine (purity $>98 \%$ ), and cytidine (purity > 98\%) were purchased from Tokyo Chemical Industry (Shanghai) (Shanghai, China). Uridine (purity $99 \%$ ), m6A (purity 97\%), and m5C (purity 98\%) were purchased from J\&K Chemical (Shanghai, China). nuclease P1 and alkaline phosphatase were purchased from Takara Biotechnology (Dalian, China). Methanol (HPLC grade) and Formic acid (chromatographic grade) were obtained from Fisher Scientific (Shanghai, China). Ultra-purified water was used throughout this study and was prepared using a Milli-Q purification system (Millipore, Milford, MA, USA). All of the other chemicals and reagents were of analytical grade.

\section{Animals}

Male Balb/c mice (6-8 weeks old and weighing 18.0-22.0 g) were obtained from Beijing HFK bioscience Co., Ltd. (Beijing, China). Mice were kept in cages under controlled conditions of $22 \pm 0.5{ }^{\circ} \mathrm{C}, 50 \pm 2.0 \% \mathrm{RH}$ and maintained with free access to standard laboratory food and water for one week before experiments.

\section{Establishment of the Epimedin C-induced hepatitis model and experimental groups}

Animals were randomly divided into three groups ( $\mathrm{n}=7$ each): the normal control group, the Epimedin $\mathrm{C}(10 \mathrm{mg} / \mathrm{kg}) \mathrm{group}$, and the Epimedin C (40 mg/kg) group. Epimedin C were completely dissolved in $0.9 \%$ saline before passing through a 0.22 $\mu \mathrm{m}$ cell strainer. The Epimedin $\mathrm{C}$ groups were intragastrically administered single doses of $10 \mathrm{and} 40 \mathrm{mg} / \mathrm{kg}$ body weight of Epimedin C per day, and the normal control group were given the same volume of saline. After four weeks of intragastric 
administration, all mice were sacrificed, and blood samples and liver tissues were collected. The procedures for the present study were approved by the Guide for the Care set by the National Institutes of Health.

\section{Assessment of liver injury}

Serum alanine transaminase (ALT) and aspartate transaminase (AST) contents in serum were analyzed using colorimetric tests (Nanjing Jiancheng Bioengineering Research Institute, Nanjing, China). Liver tissues fixed in 4\% paraformaldehyde were embedded in paraffin using a tissue procedure, and 4- $\mu$ m-thick slices were cut and stained with hematoxylin and eosin (H\&E) reagent. Photomicrographs were observed with a light microscope to evaluate liver injury.

\section{LC-MS/MS instruments and conditions}

The LC was performed using an ExionLCTM analytical (UPLC) system (AB Sciex, USA). Chromatographic separation was carried out on a Kinetex® $2.6 \mu \mathrm{m}$ Polar C18 100A LC column (100 mm × $2.1 \mathrm{~mm}$ i.d.). The flow rate was $0.3 \mathrm{~mL} / \mathrm{min}$. The mobile phase included ultra-purified water containing $0.1 \%$ formic acid (solvent $A$ ) and methanol (solvent $B$ ) in a linear gradient. The gradient program was as follows: 0 to $0.5 \mathrm{~min}, 95 \% \mathrm{~A} ; 0.5$ to $3 \mathrm{~min}, 95$ to $30 \% \mathrm{~A} ; 3$ to $4 \mathrm{~min}, 30 \% \mathrm{~A} ; 4$ to $4.1 \mathrm{~min}$, 30 to $95 \% \mathrm{~A} ; 4.1$ to $6 \mathrm{~min}, 95 \% \mathrm{~A}$. The injection volume was $10 \mu \mathrm{L}$ and the total run time was $8 \mathrm{~min}$. The temperature of the autosampler was set at $4{ }^{\circ} \mathrm{C}$, and the column temperature was maintained at $40{ }^{\circ} \mathrm{C}$. MS/MS analysis was carried out on a Qtrap 6500 mass spectrometer (AB Sciex, Redwood City, CA, USA) equipped with Turbo lonspray interface operating in positive ESI mode. The instrument was operated with an ion spray voltage of $4.5 \mathrm{kV}$ and a heater gas temperature of $500{ }^{\circ} \mathrm{C}$. Mass-dependent parameters (declustering potential, entrance potential, collision energy, and collision cell exit potential) were set to the optimal values obtained by automated optimization. Data acquisition was achieved by multiple reaction monitoring (MRM). The precursor-product ion pair and the optimal values of mass parameters are listed in Table 1. Positive ion mode was used and the dwell time was set at $100 \mathrm{~ms}$. Data acquisition was generated and processed using the Analyst 1.6.2 software (AB Sciex).

Table 1

Multiple reaction monitoring transitions and optimized mass parameters for the analytes

\begin{tabular}{|lllllll|}
\hline Analytes & Precursor ion & Product ion & DP & EP & CE & CXP \\
& $(\mathrm{m} / \mathbf{z})$ & $(\mathrm{m} / \mathbf{z})$ & $(\mathrm{V})$ & $(\mathrm{V})$ & $\mathbf{( V )}$ & $(\mathrm{V})$ \\
\hline Adenosine (A) & 268.1 & 136.1 & 30 & 10 & 22 & 10 \\
\hline Uridine (U) & 245.0 & 113.1 & 12 & 10 & 12 & 10 \\
\hline Cytidine (C) & 244.1 & 112.0 & 30 & 10 & 13 & 10 \\
\hline Guanosine (G) & 284.2 & 152.1 & 30 & 10 & 15 & 10 \\
\hline N6-methyladenosine (m6A) & 282.2 & 150.2 & 30 & 10 & 24 & 10 \\
\hline N5-methylcytidine (m5C) & 258.2 & 126.1 & 30 & 10 & 15 & 10 \\
\hline Lamivudine (IS) & 230.2 & 112.0 & 30 & 10 & 14 & 10 \\
\hline DP: declustering potential; EP: entrance potential; CE: collision energy; CXP: collision cell exit potential \\
\hline
\end{tabular}

\section{Preparation of calibration standards and QC samples}

Stock solutions for calibration and quality control (QC) were accurately weighed and dissolved in dimethylsulfoxide ( $2 \%$ of the total volume) before adding an appropriate volume of methanol to final concentration of $1 \mathrm{mg} / \mathrm{mL}$. Working solutions were prepared by serially diluting the stock solutions with water, and then the corresponding working solutions were mixed to prepare mixed working solutions with concentration in the ranges of $160-80000 \mathrm{pg} / \mathrm{mL}$ for $\mathrm{A}, \mathrm{C}, \mathrm{m} 5 \mathrm{C}$ and $\mathrm{m} 6 \mathrm{~A}, 0.8-400$ $\mathrm{ng} / \mathrm{mL}$ for $\mathrm{G}$, and $8-4000 \mathrm{ng} / \mathrm{mL}$ for $\mathrm{U}$. The stock solution $(1 \mathrm{mg} / \mathrm{mL})$ of the IS was dissolved in water to $4 \mathrm{ng} / \mathrm{mL}$ containing 
$0.4 \%$ formic acid. All solutions were kept at $-20^{\circ} \mathrm{C}$ and brought to room temperature before use. The calibration standards were prepared by spiking $10 \mu \mathrm{L}$ of the corresponding working solutions mentioned above into $30 \mu \mathrm{L}$ of mixtures of nuclease P1 (0.1 U) and alkaline phosphatase $(2 \mathrm{U})$ to yield concentrations of 40, 120, 500, 1000, 2000, 4000, 8000 and $20000 \mathrm{pg} / \mathrm{mL}$ for $A, C, m 5 C$ and m6A, 0.2, 0.6, 2.5, 5, 10, 20, 40 and $100 \mathrm{ng} / \mathrm{mL}$ for $\mathrm{G}$, and 2, 6, 25, 50, 100, 200400 and $1000 \mathrm{ng} / \mathrm{mL}$ for U. The QC samples were prepared in the same way as the calibration samples at three concentrations 120, 1600 and 16000 $\mathrm{pg} / \mathrm{mL}$ for $\mathrm{A}, \mathrm{C}, \mathrm{m} 5 \mathrm{C}$ and $\mathrm{m} 6 \mathrm{~A}, 0.6,8,80 \mathrm{ng} / \mathrm{mL}$ for $\mathrm{G}$ and 6,80 and $800 \mathrm{ng} / \mathrm{mL}$ for $\mathrm{U}$.

\section{RNA isolation from liver tissues and Enzymatic digestion of the mRNA}

$100 \mathrm{mg}$ of liver tissue was completely disrupted and homogenized into $1 \mathrm{~mL}$ TRIzol reagent. Then, the total RNA of liver tissue was isolated according to the manufacturer's instructions. After analyzed by a NanoDrop One (Thermo Scientific), the Dynabeads ${ }^{\circledR}$ mRNA Purification Kit (Ambion) was used to enrich mRNA. The contaminant DNA was removed from the mRNA samples by using DNase, and the concentration was analyzed by a Qubit 3.0 Fluorometer (Invitrogen).

Referring to the methods reported, enzymatic digestion of the mRNA was performed[16]. The mixture sample (30 $\mu \mathrm{L})$ for $\mathrm{m} 6 \mathrm{~A}$ and $\mathrm{m} 5 \mathrm{C}$ testing included $100 \mathrm{ng}$ mRNA, $1 \mu \mathrm{L}$ of nuclease P1 $(0.1 \mathrm{U} / \mu \mathrm{L}$, Takara), and $2 \mu \mathrm{L}$ of alkaline phosphatase (calf intestine, $1 \mathrm{U} / \mu \mathrm{L}$, Takara). The mixture sample $(30 \mu \mathrm{L})$ for $\mathrm{A}, \mathrm{U}, \mathrm{C}$ and $\mathrm{G}$ testing included $0.1 \mathrm{ng} \mathrm{mRNA}, 1 \mu \mathrm{L}$ of nuclease $\mathrm{P} 1$ $(0.1 \mathrm{U} / \mu \mathrm{L}$, Takara), and $2 \mu \mathrm{L}$ of alkaline phosphatase (calf intestine, $1 \mathrm{U} / \mu \mathrm{L}$, Takara). After fully vortexed, both high and low concentration mixtures were incubated at $37^{\circ} \mathrm{C}$ for $12 \mathrm{~h}$. Then, $10 \mu \mathrm{L}$ IS solution (IS, lamivudine, $4 \mathrm{ng} / \mathrm{mL}$ ) containing $0.4 \%$ formic acid was added. The mixtures were vortexed for $15 \mathrm{~s}$ and transferred into ultrafiltration tubes (MW cutoff of $3 \mathrm{kDa}$, Pall Corporation), and centrifuged at $4{ }^{\circ} \mathrm{C}, 14000 \times \mathrm{g}$ for $15 \mathrm{~min}$. The filtrate was added to an autosampler vial, then $10 \mu \mathrm{L}$ of the filtrate was used for UPLC-MS/MS analysis.

\section{Method validation}

The analytical methodology was under the guidelines set by the United States Food and Drug Administration [23] and the Chinese Pharmacopoeia Commission [24].

The selectivity was evaluated by comparing chromatograms of mRNA-free blank enzymolysis matrix, blank enzymolysis matrix with all analytes, and a liver mRNA enzymolysis sample containing IS from a mouse after Epimedin $\mathrm{C}$ treatment. The absence of peaks at retention times of seven analytes indicated no interference in the test samples.

After detection of the upper limit of the quantification (ULOQ) samples, blank samples were injected to evaluate the carryover effects. The response peak of any analytes must be $<10 \%$ of the lower limit of the quantification (LLOQ) samples.

The linearity was investigated by plotting the peak-area ratios of the analytes $(A, U, C, G, m 6 A$ and $m 5 C)$ to the IS versus the concentrations of the calibration standards. The calibration equations were fitted using a weighed least-squares linear regression analysis (weighing factor of $1 / x^{2}$ ). The accuracy, expressed as the mean relative error (RE, \%), should be $\leq 20 \%$ for LLOQ and $\leq 15 \%$ for the other seven concentrations of the calibration standards.

To assess the precision and accuracy of the method, five replicates of QC (at three concentration levels) and LLOQ were prepared and analyzed within three validation days. Both the accuracy (RE, \%) and intra- and inter- precision (RSD, \%) for LLOQ should be less than or equal to $20 \%$. The accuracy and precision for the QC levels should be within $\pm 15 \%$.

To determine whether matrix components affected the ion suppression or enhancement in the method, the matrix effect (ME) was assessed by comparing the corresponding peak area responses of enzymolysis matrix with all analytes and the blank samples in which the enzymolysis matrix was replaced with water. In this method, the variability values of the MEs (RSD, \%) should be less than $15 \%$.

To evaluate the stability of the analytes in the enzymolysis matrix during sample preparation and storage, the low and high QC concentration levels in different storage conditions were detected. The storage conditions included room temperature for 
$6 \mathrm{~h}$, three freeze-thaw cycles, autosampler at ambient temperature for $20 \mathrm{~h}$, and freezing at $-20{ }^{\circ} \mathrm{C}$ for 30 days. The analytes were stable when $85-115 \%$ of the initial concentration was retained.

The dilution integrity was assessed by testing the solution which was diluted 100-fold with blank enzymolysis matrix before ultra-filtration from highly concentrated samples above the upper limit of standard curves. The accuracy and precision should be within $\pm 15 \%$.

\section{Data analysis}

The data were presented as the arithmetic mean \pm SD. Statistical analyses were performed using SPSS software for Windows. Statistical significance was assessed by unpaired two-tailed Student's t-test between two samples. $p$ value $<0.05$ was considered statistically significant.

\section{Results}

\section{Chromatography and mass spectrometry}

Ionization was achieved using the positive ion-monitoring mode with ESI. The precursor ions and product ions of six nucleosides and lamivudine (IS) were detected using multiple reaction monitoring (MRM). The ion transition (shown in Fig. 1) for adenosine was $\mathrm{m} / \mathrm{z} 268.1 \rightarrow 136.1$, for uridine was $\mathrm{m} / \mathrm{z} 245.0 \rightarrow 113.1$, for cytidine was $\mathrm{m} / \mathrm{z} 244.1 \rightarrow 112.0$, for guanosine was $\mathrm{m} / \mathrm{z} 284.2 \rightarrow 152.1$, for N6-methyladenosine was $\mathrm{m} / \mathrm{z} 282.2 \rightarrow 150.2$, for N5-methylcytidine was $\mathrm{m} / \mathrm{z}$ 258.2 $\rightarrow 126.1$,and for lamivudine (IS) was $\mathrm{m} / \mathrm{z} 230.2 \rightarrow 112.0$.

\section{Selectivity, linearity, and carryover of method validation}

Typical chromatograms of six nucleosides and lamivudine (IS) are shown in Fig. 2. No significant interference was observed at the retention times of $\mathrm{A}, \mathrm{U}, \mathrm{C}, \mathrm{G}, \mathrm{m} 6 \mathrm{~A}, \mathrm{~m} 5 \mathrm{C}$ and IS which were 1.73, 1.31, 0.91, 1.94, 2.46, 1.07 and 1.56 min, respectively. The calibration curves were linear over the concentration ranges of $40-20000 \mathrm{pg} / \mathrm{mL}(r>0.99, \mathrm{n}=8)$ for $\mathrm{A}, \mathrm{C}, \mathrm{m} 5 \mathrm{C}$ and $\mathrm{m} 6 \mathrm{~A}$, $0.2-100 \mathrm{ng} / \mathrm{mL}$ for $\mathrm{G}$, and $2-1000 \mathrm{ng} / \mathrm{mL}$ for $\mathrm{U}(r>0.99, \mathrm{n}=8)$. Carryover effects were absent for analytes.

\section{Accuracy and precision}

Three batches of LLOQ and QC samples were evaluated to obtain the intra- and interday precision and accuracy with the current method. The validation results of accuracy and precision for $\mathrm{A}, \mathrm{U}, \mathrm{C}, \mathrm{G}, \mathrm{m6A}$ and $\mathrm{m} 5 \mathrm{C}$ are listed in Table 2, which demonstrated that the values of RSD and RE were all inside the acceptable variability limits. It indicates that the method is accurate and precise. 
Table 2

Precision and accuracy data for the quantification of the six nucleosides in mRNA $(n=5)$

\begin{tabular}{|c|c|c|c|c|c|}
\hline \multirow[t]{2}{*}{ Analytes } & \multicolumn{2}{|c|}{ Concentration levels (mean $\pm \mathrm{SD}, \mathrm{pg} / \mathrm{mL}$ ) } & \multicolumn{2}{|c|}{ RSD (\%) } & \multirow{2}{*}{$\begin{array}{l}\text { RE (\%) } \\
\text { Accuracy }\end{array}$} \\
\hline & Added & Measured & Intra-day & Inter-day & \\
\hline Adenosine & 40 & $40.8 \pm 1.9$ & 6.5 & 4.3 & 2.0 \\
\hline \multirow[t]{3}{*}{ (A) } & 120 & $133.3 \pm 3.1$ & 3.9 & 2.0 & 11.1 \\
\hline & 1600 & $1792.7 \pm 33.7$ & 3.6 & 1.4 & 12.0 \\
\hline & 16000 & $15120.0 \pm 270.4$ & 4.0 & 1.0 & -5.5 \\
\hline Uridine & 2000 & $1919.3 \pm 96.0$ & 6.5 & 4.7 & -4.0 \\
\hline \multirow[t]{3}{*}{$(U)$} & 6000 & $6101.3 \pm 220.7$ & 7.4 & 2.5 & 1.7 \\
\hline & 80000 & $83680.0 \pm 1235.9$ & 2.6 & 1.2 & 4.6 \\
\hline & 800000 & $710133.3 \pm 10405.1$ & 2.1 & 1.3 & -11.2 \\
\hline Cytidine & 40 & $36.7 \pm 2.3$ & 0.5 & 6.8 & -8.3 \\
\hline \multirow[t]{3}{*}{ (C) } & 120 & $117.3 \pm 5.4$ & 4.8 & 4.5 & -2.3 \\
\hline & 1600 & $1672.7 \pm 26.0$ & 1.5 & 1.6 & 4.5 \\
\hline & 16000 & $15953.3 \pm 247.5$ & 1.2 & 1.6 & -0.3 \\
\hline Guanosine & 200 & $195.0 \pm 12.0$ & 12.7 & 4.1 & -2.5 \\
\hline \multirow[t]{3}{*}{ (G) } & 600 & $630.4 \pm 21.8$ & 6.4 & 2.7 & 5.1 \\
\hline & 8000 & $8472.0 \pm 280.3$ & 4.3 & 3.1 & 5.9 \\
\hline & 80000 & $78180.0 \pm 1894.1$ & 4.5 & 1.9 & -2.3 \\
\hline N6-methyladenosine & 40 & $36.2 \pm 2.0$ & 13.8 & 1.9 & -9.5 \\
\hline \multirow[t]{3}{*}{$\left(m^{6} A\right)$} & 120 & $131.2 \pm 6.9$ & 2.4 & 5.6 & 9.3 \\
\hline & 1600 & $1733.3 \pm 96.0$ & 7.2 & 5.2 & 8.3 \\
\hline & 16000 & $15806.1 \pm 196.9$ & 1.2 & 1.2 & -1.2 \\
\hline N5-methylcytidine & 40 & $38.4 \pm 1.6$ & 2.1 & 4.3 & -4.0 \\
\hline \multirow[t]{3}{*}{$\left(m^{5} \mathrm{C}\right)$} & 120 & $122.3 \pm 3.3$ & 4.2 & 2.3 & 1.9 \\
\hline & 1600 & $1697.3 \pm 39.9$ & 6.0 & 0.6 & 6.1 \\
\hline & 16000 & $15726.7 \pm 286.5$ & 3.3 & 1.4 & -1.7 \\
\hline
\end{tabular}

\section{Matrix effects and stability}

The results of ME and extraction recovery were evaluated using QC samples at the low and high QC levels. The IS-corrected matrix factors of the six different batches of enzymolysis matrix at low- and high-concentrations were $96.1 \pm 3.1$ and $97.8 \pm$ $3.1 \%$ for $A, 105.4 \pm 8.3$ and $100.0 \pm 3.2 \%$ for $U, 100.2 \pm 7.5$ and $97.1 \pm 4.2 \%$ for $C, 100.1 \pm 4.6$ and $98.6 \pm 4.9 \%$ for $G, 98.3 \pm 3.0$ and $98.5 \pm 3.7 \%$ for $\mathrm{m} 6 \mathrm{~A}$, and $100.5 \pm 5.0$ and $95.0 \pm 3.9 \%$ for $\mathrm{m} 5 \mathrm{C}$, respectively. These data indicated that the MEs for all the analytes were negligible following the current method.

The stability results of the analytes are summarized in Table 3. A, U, C, G, m6A and m5C remained at room temperature for 6 $\mathrm{h}$ and after three freeze-thaw cycles. All the analytes were also stable in the autosampler at ambient temperature for $20 \mathrm{~h}$ and 
after freezing at $-20^{\circ} \mathrm{C}$ for 30 days.

Table 3

The stability test results of the six nucleosides in enzymolysis matrix under various storage conditions $(n=5)$

\begin{tabular}{|c|c|c|c|c|c|c|c|c|c|}
\hline \multirow[t]{2}{*}{ Analytes } & \multirow[t]{2}{*}{$\begin{array}{l}\text { Added } \\
(\mathrm{pg} / \mathrm{mL})\end{array}$} & \multicolumn{2}{|c|}{$\begin{array}{l}\text { Room } \\
\text { temperature for } 6 \\
\text { h }\end{array}$} & \multicolumn{2}{|c|}{$\begin{array}{l}\text { Autosampler for } \\
20 \mathrm{~h}(\mathrm{RT})\end{array}$} & \multicolumn{2}{|c|}{$\begin{array}{l}\text { Three freeze-thaw } \\
\text { cycles }\end{array}$} & \multicolumn{2}{|c|}{$\begin{array}{l}\text { Freezing for } 30 \\
\text { days }\left(-20^{\circ} \mathrm{C}\right)\end{array}$} \\
\hline & & $\begin{array}{l}\text { Measured } \\
(\mathrm{pg} / \mathrm{mL})\end{array}$ & $\begin{array}{l}\text { RE } \\
(\%)\end{array}$ & $\begin{array}{l}\text { Measured } \\
(\mathrm{pg} / \mathrm{mL})\end{array}$ & $\begin{array}{l}\text { RE } \\
(\%)\end{array}$ & $\begin{array}{l}\text { Measured } \\
(\mathrm{pg} / \mathrm{mL})\end{array}$ & $\begin{array}{l}\text { RE } \\
(\%)\end{array}$ & $\begin{array}{l}\text { Measured } \\
(\mathrm{pg} / \mathrm{mL})\end{array}$ & $\begin{array}{l}\mathrm{RE} \\
(\%)\end{array}$ \\
\hline \multirow[t]{2}{*}{ Adenosine } & 120 & $\begin{array}{l}130.0 \pm \\
2.1\end{array}$ & 8.3 & $\begin{array}{l}133.0 \pm \\
1.0\end{array}$ & 10.8 & $\begin{array}{l}134.2 \pm \\
3.6\end{array}$ & 11.8 & $\begin{array}{l}133.0 \pm \\
1.6\end{array}$ & 10.8 \\
\hline & 16000 & $\begin{array}{l}15360.0 \\
\pm 230.2\end{array}$ & -4.0 & $\begin{array}{l}15380.0 \\
\pm 164.3\end{array}$ & -3.9 & $\begin{array}{l}15240.0 \\
\pm 54.8\end{array}$ & -4.8 & $\begin{array}{l}14840.0 \\
\pm 167.3\end{array}$ & -7.3 \\
\hline \multirow[t]{2}{*}{ Uridine } & 6000 & $\begin{array}{l}6316.0 \pm \\
170.7\end{array}$ & 5.3 & $\begin{array}{l}6052.0 \pm \\
169.9\end{array}$ & 0.9 & $\begin{array}{l}5986.0 \pm \\
141.2\end{array}$ & -0.2 & $\begin{array}{l}5868.0 \pm \\
140.2\end{array}$ & -2.2 \\
\hline & 800000 & $\begin{array}{l}706000.0 \\
\pm 12308.5\end{array}$ & -11.8 & $\begin{array}{l}688800.0 \\
\pm 6760.2\end{array}$ & -13.9 & $\begin{array}{l}687200.0 \\
\pm 15073.2\end{array}$ & -14.1 & $\begin{array}{l}716600.0 \\
\pm 13794.9\end{array}$ & -10.4 \\
\hline \multirow[t]{2}{*}{ Cytidine } & 120 & $\begin{array}{l}120.8 \pm \\
2.9\end{array}$ & 0.7 & $\begin{array}{l}121.0 \pm \\
1.9\end{array}$ & 0.8 & $\begin{array}{l}119.0 \pm \\
4.4\end{array}$ & -0.8 & $\begin{array}{l}117.2 \pm \\
4.1\end{array}$ & -2.3 \\
\hline & 16000 & $\begin{array}{l}16140.0 \\
\pm 240.8\end{array}$ & 0.9 & $\begin{array}{l}16040.0 \\
\pm 230.2\end{array}$ & 0.3 & $\begin{array}{l}16080.0 \\
\pm 238.7\end{array}$ & 0.5 & $\begin{array}{l}15980.0 \\
\pm 228.0\end{array}$ & -0.1 \\
\hline \multirow[t]{2}{*}{ Guanosine } & 600 & $\begin{array}{l}653.0 \pm \\
16.3\end{array}$ & 8.8 & $\begin{array}{l}625.8 \pm \\
14.8\end{array}$ & 4.3 & $\begin{array}{l}628.2 \pm \\
14.8\end{array}$ & 4.7 & $\begin{array}{l}605.2 \pm \\
28.1\end{array}$ & 0.9 \\
\hline & 80000 & $\begin{array}{l}79200.0 \\
\pm 748.3\end{array}$ & -1.0 & $\begin{array}{l}77520.0 \\
\pm 1158.4\end{array}$ & -3.1 & $\begin{array}{l}76300.0 \\
\pm 1647.7\end{array}$ & -4.6 & $\begin{array}{l}77320.0 \\
\pm 2008.0\end{array}$ & -3.4 \\
\hline \multirow[t]{2}{*}{$\mathrm{m} 6 \mathrm{~A}$} & 120 & $\begin{array}{l}132.4 \pm \\
3.0\end{array}$ & 10.3 & $\begin{array}{l}126.0 \pm \\
3.4\end{array}$ & 5.0 & $\begin{array}{l}123.8 \pm \\
3.0\end{array}$ & 3.2 & $\begin{array}{l}132.2 \pm \\
12.1\end{array}$ & 10.2 \\
\hline & 16000 & $\begin{array}{l}15962.0 \\
\pm 205.7\end{array}$ & -0.2 & $\begin{array}{l}15561.0 \\
\pm 218.9\end{array}$ & -2.7 & $\begin{array}{l}15490.8 \\
\pm 269.4\end{array}$ & -3.2 & $\begin{array}{l}15841.8 \\
\pm 281.8\end{array}$ & -1.0 \\
\hline \multirow[t]{2}{*}{$\mathrm{m} 5 \mathrm{C}$} & 120 & $\begin{array}{l}123.4 \pm \\
3.8\end{array}$ & 2.8 & $\begin{array}{l}121.6 \pm \\
2.2\end{array}$ & 1.3 & $\begin{array}{l}120.0 \pm \\
2.2\end{array}$ & 0 & $\begin{array}{l}122.2 \pm \\
3.7\end{array}$ & 1.8 \\
\hline & 16000 & $\begin{array}{l}15720.0 \\
\pm 130.4\end{array}$ & -1.8 & $\begin{array}{l}15600.0 \\
\pm 100.0\end{array}$ & -2.5 & $\begin{array}{l}15600.0 \\
\pm 308.2\end{array}$ & -2.5 & $\begin{array}{l}15980.0 \\
\pm 249.0\end{array}$ & -0.1 \\
\hline
\end{tabular}

\section{Dilution integrity}

Table 4 shows the results of the dilution integrity. The precision and accuracy of the dilution test at the low and high concentration levels were within the acceptable criteria, indicated that $A, U, C, G, m 6 A$ and $m 5 C$ were assayed reliably by diluting 100 -fold with blank enzymolysis matrix. Samples could be tested by dilution when the analyte concentration exceeded the linear range of the standard curve. 
Table 4

Precision and accuracy of the dilution QC samples $(n=5)$

\begin{tabular}{|c|c|c|c|c|c|c|}
\hline Analytes & $\begin{array}{l}\text { added } \\
\text { (ng/mL) }\end{array}$ & $\begin{array}{l}\text { Dilution } \\
\text { factor }\end{array}$ & $\begin{array}{l}\text { Caculated } \\
\text { (pg/mL) }\end{array}$ & $\begin{array}{l}\text { Measured } \\
(\mathrm{pg} / \mathrm{mL})\end{array}$ & $\begin{array}{l}\text { RSD } \\
(\%)\end{array}$ & $\begin{array}{l}\text { RE } \\
(\%)\end{array}$ \\
\hline \multirow[t]{2}{*}{ Adenosine } & 12 & 100 & 120 & $137.8 \pm 2.2$ & 1.6 & 14.8 \\
\hline & 1600 & 100 & 16000 & $14940.0 \pm 167.3$ & 1.1 & -6.6 \\
\hline \multirow[t]{2}{*}{ Uridine } & 600 & 100 & 6000 & $5862.0 \pm 99.3$ & 1.7 & -2.3 \\
\hline & 80000 & 100 & 800000 & $\begin{array}{l}716000.0 \pm \\
10583.0\end{array}$ & 1.5 & -10.5 \\
\hline \multirow[t]{2}{*}{ Cytidine } & 12 & 100 & 120 & $115.8 \pm 5.4$ & 4.6 & -3.5 \\
\hline & 1600 & 100 & 16000 & $16100.0 \pm 339.1$ & 2.1 & 0.6 \\
\hline \multirow[t]{2}{*}{ Guanosine } & 60 & 100 & 600 & $635.2 \pm 26.0$ & 4.1 & 5.9 \\
\hline & 8000 & 100 & 80000 & $78920.0 \pm 1856.6$ & 2.4 & -1.4 \\
\hline \multirow[t]{2}{*}{$\mathrm{m}^{6} \mathrm{~A}$} & 12 & 100 & 120 & $126.4 \pm 10.2$ & 8.0 & 5.3 \\
\hline & 1600 & 100 & 16000 & $15631.2 \pm 212.5$ & 1.4 & -2.3 \\
\hline \multirow[t]{2}{*}{$m^{5} \mathrm{C}$} & 12 & 100 & 120 & $125.8 \pm 4.5$ & 3.6 & 4.8 \\
\hline & 1600 & 100 & 16000 & $16540.0 \pm 320.9$ & 1.9 & 3.4 \\
\hline
\end{tabular}

\section{Epimedin C induced liver injury}

Hematoxylin and eosin staining of the liver was performed in order to evaluate the pathological changes in liver. Epimedin C challenge increased the inflammatory cell infiltration (the red arrow) and vacuolar degeneration (the black arrow) observed in liver, and these effects were induced with the increased dose of Epimedin C (Fig. 3). Serum aminotransferase levels were in good agreement with histopathological changes in our study. The serum levels of transaminase were measured to evaluate hepatocellular damage. The results showed that serum ALT and AST levels increased after intravenous Epimedin C administration compared with the normal control group (Fig. 3).

\section{Application for quantifying the nucleosides}

The mean concentration levels of $\mathrm{m} 6 \mathrm{~A}$ and $\mathrm{m} 5 \mathrm{C}$ in prepared test samples of mice liver mRNA in the control and Epimedin $\mathrm{C}$ induced liver injury model groups are presented in Fig. 4. The ratio of m6A to $A\left(m 6 A / A \%=C_{m 6 A} / C_{A} \times \%\right)$ and $m 5 C$ to $C$ ( $\mathrm{m} 5 \mathrm{C} / \mathrm{C} \%=\mathrm{C}_{\mathrm{m} 5 \mathrm{c}} / \mathrm{C}_{\mathrm{C}} \times \%$ ) expressed the content of modified nucleoside in mouse liver mRNA. The results showed that compared with the normal control group, the concentration levels of m6A and m5C significantly increased, respectively. Furthermore, the ratio of $\mathrm{m} 6 \mathrm{~A} / \mathrm{A}$ and $\mathrm{m} 5 \mathrm{C} / \mathrm{C}$ in the mice liver mRNA in the Epimedin $\mathrm{C}$ groups were higher than that in the control group. According to these results, it could be indicated that epigenetic modification may change may in mice liver after Epimedin C treatment.

\section{Discussion}

As the widely use in China, Epimedium has been frequently reported to cause liver injury[4-5]. Epimedin $C$ is one of the main active ingredient of Epimedium. Some studies have indicated the potential hepatotoxicity[6-8], but the mechanism of Epimedin C-induced liver damage has not been studied. To the best of our knowledge, methylation modification disorders of mRNA are closely related to the occurrence and development of many liver diseases. The study of mRNA methylation in Epimedin C-induced liver injury may contribute to clarify the liver toxicity mechanism of Epimedin C, and provide guidance for 
Chinese herbal medicine in clinical practice. For this reason, it is important to precisely quantify the content of mRNA methylation in Epimedin C-induced liver injury.

Because of the high selectivity and sensitivity, high performance liquid chromatography-tandem mass spectrometry is one of the best means for the quantification of bio-samples at present[18]. Some methods have been utilized to detected m6A or $\mathrm{m} 5 \mathrm{C}$ in DNA and RNA samples, but it is lack of method for the simultaneous determination of six nucleosides to evaluate the content of modified nucleosides using the ratio of $\mathrm{m} 6 \mathrm{~A}$ to $\mathrm{A}$ and $\mathrm{m} 5 \mathrm{C}$ to $\mathrm{C}$. Combined with the change of $\mathrm{m} 6 \mathrm{~A}$ and $\mathrm{m} 5 \mathrm{C}$ levels in samples, the ratio of $m 6 A$ to $A$ and $m 5 C$ to $C$ can better indicate the level of mRNA methylation in liver injury model. It is known that mRNA is unstable and easily decomposed. Consequently, an purification and enzymatic digestion method was performed before detection by LC-MS/MS.

This present method was successfully applied to the determination of six nucleoside levels in mice liver mRNA in Epimedin Cinduced liver injury model. Due to consisting of multiple compounds in mice plasma, the simultaneous quantitation of six nucleoside encounters the great challenge in short running time using UPLC. Multiple reaction monitoring, a highly specific technique, can be used for quantifying the targeted analyte without the considering of baseline chromatographic separation. The chromatographic conditions were optimized for the high sensitivity and fast separation to avoid the low MS response caused by the potential mutual ionization suppression in ESI[25]. A Kinetex® $2.6 \mu \mathrm{m}$ Polar C18 100A LC column was proved to be more suitable for the separation of the targeted compounds in the sample. And as results, ultra-purified water containing $0.1 \%$ formic acid / methanol in a linear gradient was the optimum mobile phase to achieve the chromatogram.

In this study, a selective, rapid and sensitive method was established using high performance liquid chromatography-tandem mass spectrometry to simultaneous determination of six nucleosides in mRNA. The precision and accuracy of this method were adequately validated under the guidelines for bioanalytical method validation. The differences of mass spectrometry response values between these six nucleosides led to the different ranges of standard curve. Furthermore, because of the much higher concentrations of $\mathrm{A}, \mathrm{U}, \mathrm{C}$ and $\mathrm{G}$ than that of $\mathrm{m} 6 \mathrm{~A}$ and $\mathrm{m} 5 \mathrm{C}$, the highly sensitive detector is prone to saturation effect when the concentrations of $\mathrm{m} 6 \mathrm{~A}$ and $\mathrm{m} 5 \mathrm{C}$ are within the standard curve range but the remaining part is at high concentration. Therefore, an alternative solution is diluting the concentration when detecting A, U, C and G.

Our study showed the changes of m6A and $\mathrm{m} 5 \mathrm{C}$ in mice liver mRNA after Epimedin $\mathrm{C}$ treatment, but the relationship between modified nucleosides and the mechanism of Epimedin C-induced liver injury is not well understood, which requires further investigation. This study may offer a new idea and approach for studying the mechanism of Epimedin C-induced liver injury.

\section{Conclusions}

This analysis method was successfully applied to the detection of six liver mRNA nucleosides levels in Epimedin C-induced liver injury. The method has qualified precision and accuracy with the guidelines for bio-analytical method validation. The results showed that Epimedin $\mathrm{C}$ led to liver injury, and epigenetic modification changed in mice liver after Epimedin $\mathrm{C}$ treatment. Therefore, it is suggested that the modified nucleoside m6A and m5C might be associated with liver injury. It might contribute to prevent the hepatotoxicity of Epimedium in clinical treatment and provide new idea for further research on the mechanism of herbal medicine-induced liver injury.

\section{Abbreviations}
A: adenosine
U: uridine
C: cytidine
G: guanosine 
m6A: N6-methyladenosine

m5C: N5-methylcytidine

ME: matrix effect

MRM: multiple reaction monitoring

mRNA: messenger ribonucleic acid

ALT: alanine transaminase

AST: aspartate transaminase

LC-MS/MS: liquid chromatography tandem mass spectrometry

QC: quality control

\section{Declarations}

\section{Availability of data and materials}

The datasets supporting the conclusion of this article are included within the article and its additional files.

\section{Acknowledgments}

Not applicable.

\section{Funding}

This work was supported by the National Natural Science Foundation of China (Grant no. 31870809 and 81801335) and the Henan Medical Science and Technology Research Project (Grant No. 2018020039).

\section{Author information}

Affiliations

Department of Pharmacy, the First Affiliated Hospital of Zhengzhou University, Zhengzhou, P. R. China

Zhizhen Song, Zeyun Li, Xueqian Wen, Ruijuan Liu, Xin Tian

Henan Key Laboratory of Precision Clinical Pharmacy, Zhengzhou, P. R. China

Zhizhen Song, Zeyun Li, Xueqian Wen, Ruijuan Liu, Xin Tian

\section{Contributions}

ZZS designed the study and drafted the initial manuscript; ZZS, ZYL and XQW performed the experiments and contributed to the initial data analysis. ZZS and XQW prepared figures and tables. ZYL, RJL and XT revised the manuscript. All authors read and approved the final manuscript.

\section{Corresponding author}

Correspondence to Xin Tian.

\section{Ethics declarations}




\section{Ethics approval and consent to participate}

Not applicable.

\section{Consent for publication}

Not applicable.

\section{Competing interests}

There are no competing interests.

\section{References}

1. Shen T, Liu Y, Shang J, Xie Q, Li J, Yan M, et al. Incidence and Etiology of Drug-Induced Liver Injury in Mainland China. Gastroenterology. 2019;156(8):2230-41 e2211.

2. Huang S, Meng N, Chang B, Quan X, Yuan R, Li B. Anti-Inflammatory Activity of Epimedium brevicornu Maxim Ethanol Extract. J Med Food. 2018;21(7):726-33.

3. Zhang Y, Huang R, Wu L, Wang Y, Jin T, Liang Q. The complete chloroplast genome of Epimedium brevicornu Maxim (Berberidaceae), a traditional Chinese medicine herb. Mitochondrial DNA Part B Resources. 2020;5(1):588-90.

4. Ai L, Yi W, Chen L, Wang H, Huang Q. Xian-Ling-Gu-Bao protects osteoporosis through promoting osteoblast differentiation by targeting miR-100-5p/KDM6B/RUNX2 axis. In vitro cellular developmental biology Animal. 2021;57(1):3-9.

5. Wu H, Zhong Q, Wang J, Wang M, Fang F, Xia Z, et al. Beneficial Effects and Toxicity Studies of Xian-ling-gu-bao on Bone Metabolism in Ovariectomized Rats. Front Pharmacol. 2017;8:273.

6. Xie J, Xu H, Jiang J, Zhang N, Yang J, Zhao J, et al. Characterization of a novel thermostable glucose-tolerant GH1 betaglucosidase from the hyperthermophile Ignisphaera aggregans and its application in the efficient production of baohuoside I from icariin and total epimedium flavonoids. Bioorganic chemistry. 2020;104:104296.

7. Cheng Y, Yang Z, Shi J, Yang J, Zhao J, He Y, et al. Total flavonoids of Epimedium ameliorates testicular damage in streptozotocin-induced diabetic rats by suppressing inflammation and oxidative stress. Environmental toxicology. 2020;35(2):268-76.

8. Zhang L, Wang T, Zhao BS, Zhang JX, Yang S, Fan CL, et al. Effect of 2"-O-Rhamnosyl Icariside II, Baohuoside I and Baohuoside II in Herba Epimedii on Cytotoxicity Indices in HL-7702 and HepG2 Cells. Molecules. 2019; 24(7).

9. Nombela P, Miguel-Lopez B, Blanco S. The role of m(6)A, m(5)C and Psi RNA modifications in cancer: Novel therapeutic opportunities. Mol Cancer. 2021;20(1):18.

10. Xie S, Chen W, Chen K, Chang Y, Yang F, Lin A, et al. Emerging roles of RNA methylation in gastrointestinal cancers. Cancer cell international. 2020;20(1):585.

11. Chellamuthu A, Gray SG. The RNA Methyltransferase NSUN2 and Its Potential Roles in Cancer. Cells. 2020; 9(8).

12. Ma JZ, Yang F, Zhou CC, Liu F, Yuan JH, Wang F, et al. METTL14 suppresses the metastatic potential of hepatocellular carcinoma by modulating N(6) -methyladenosine-dependent primary MicroRNA processing. Hepatology. 2017;65:52943.

13. Chen M, Wei L, Law CT, Tsang FH, Shen J, Cheng CL, et al. RNA N6-methyladenosine methyltransferase-like 3 promotes liver cancer progression through YTHDF2-dependent posttranscriptional silencing of SOCS2. Hepatology. 2018;67:225470 .

14. Jian H, Zhang C, Qi Z, Li X, Lou Y, Kang Y, et al. Alteration of mRNA 5-Methylcytosine Modification in Neurons After OGD/R and Potential Roles in Cell Stress Response and Apoptosis. Frontiers in genetics. 2021;12:633681. 
15. Xiang S, Ma Y, Shen J, Zhao Y, Wu X, Li M, et al. m(5)C RNA Methylation Primarily Affects the ErbB and PI3K-Akt Signaling Pathways in Gastrointestinal Cancer. Frontiers in molecular biosciences. 2020;7:599340.

16. Liu R, Zhao F, Wei J, Yu P, Zhang J, Wang Y, et al. Determination of five nucleosides by LC-MS/MS and the application of the method to quantify $\mathrm{N}^{6}$-methyladenosine level in liver messenger ribonucleic acid of an acetaminophen-induced hepatotoxicity mouse model. J Sep Sci. 2019;42(16):2668-78.

17. Chang JS, Lin ZX, Liu YJ, Yang SM, Zhang Y, Yu XY. Ultra performance liquid chromatography-tandem mass spectrometry assay for the quantification of RNA and DNA methylation. J Pharm Biomed Anal. 2021;197:113969.

18. Guo M, Liu D, Sha Q, Geng H, Liang J, Tang D. Succinic acid enhanced quantitative determination of blood modified nucleosides in the development of diabetic nephropathy based on hydrophilic interaction liquid chromatography mass spectrometry. J Pharm Biomed Anal. 2019;164:309-16.

19. Cui X, Liang Z, Shen L, Zhang Q, Bao S, Geng Y, et al. 5-Methylcytosine RNA Methylation in Arabidopsis Thaliana. Mol Plant. 2017;10(11):1387-99.

20. Fu L, Amato NJ, Wang P, McGowan SJ, Niedernhofer LJ, Wang Y. Simultaneous Quantification of Methylated Cytidine and Adenosine in Cellular and Tissue RNA by Nano-Flow Liquid Chromatography-Tandem Mass Spectrometry Coupled with the Stable Isotope-Dilution Method. Anal Chem. 2015;87(15):7653-9.

21. Zhu Y, Zhou G, Yu X, Xu Q, Wang K, Xie D, et al. LC-MS-MS quantitative analysis reveals the association between FTO and DNA methylation. PLoS One. 2017;12(4):e0175849.

22. Hsu PJ, Shi H, Zhu AC, Lu Z, Miller N, Edens BM, et al. The RNA-binding protein FMRP facilitates the nuclear export of N6methyladenosine-containing mRNAs. The Journal of Biological Chemistry. 2019;294(52):19889-95.

23. U.S. Department of Health and Human Services (DHHS). Food and Drug Administration (FDA), Center for Drug Evaluation and Research (CDER), Center for Veterinary Medicine (CVM), Guidance for Industry, bioanalytical method validation. 2013.

24. Chinese Pharmacopoeia Commission. Chinese Pharmacopoeia, Guiding principle for bioanalytical method validation. 2015.

25. Hu Y, Wang Z, Xia FB, Yang W, Liu YC, Wan JB. Simultaneous quantification of bioactive components in Chinese herbal spirits by ultra-high performance liquid chromatography coupled to triple-quadrupole mass spectrometry (UHPLC-QQQMS/MS). Chinese Medicine. 2021;16(1):26.

\section{Figures}



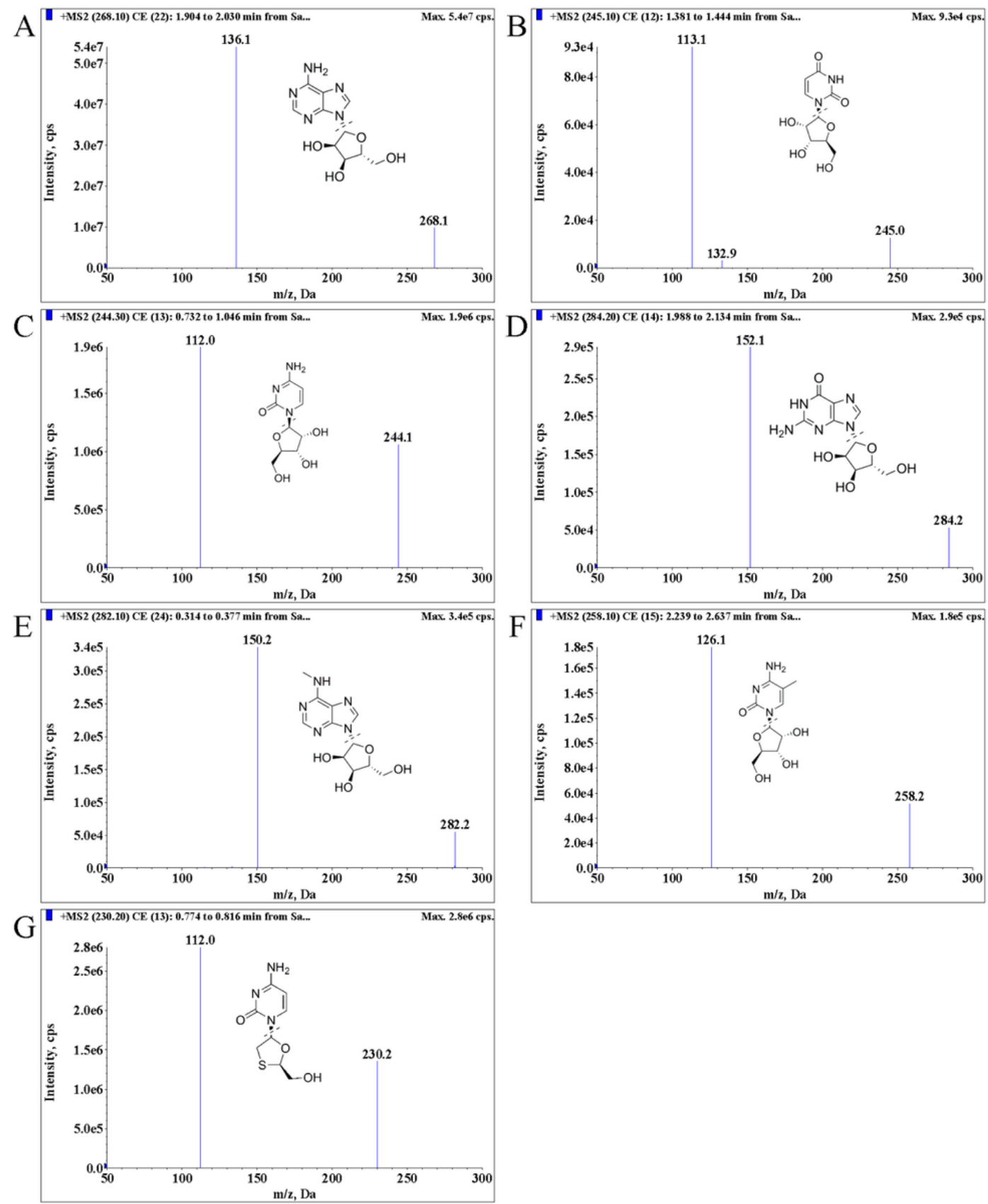

Figure 1

Product ion spectra of (A) adenosine; (B) uridine; (C) cytidine; (D) guanosine; (E) N6-methyladenosine; (F) N5-methylcytidine; (G) lamivudine. 

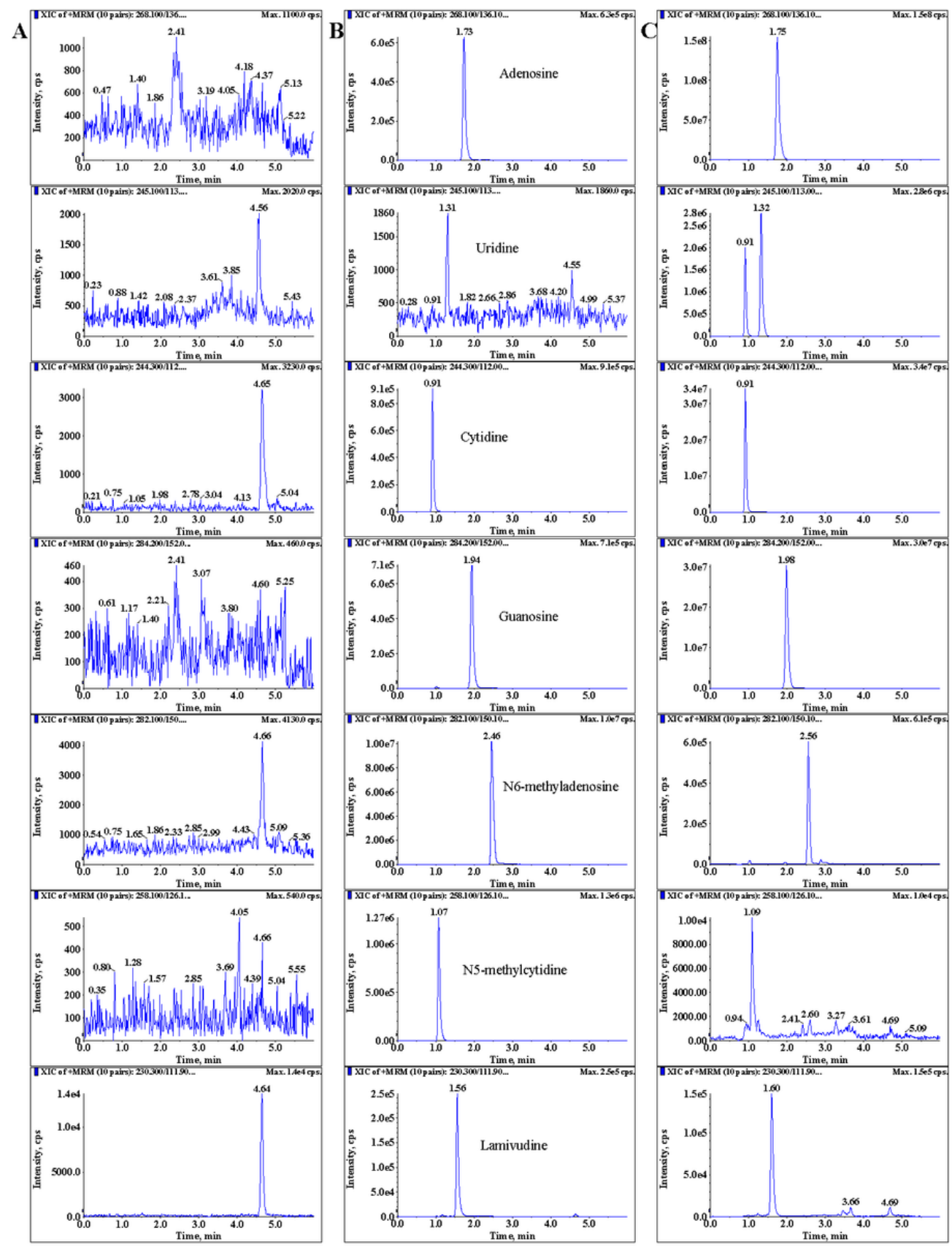

\section{Figure 2}

Typical MRM chromatograms of adenosine, uridine, cytidine, guanosine, m6A, m5C and lamivudine (IS). (A) Blank enzymolysis matrix sample; (B) blank enzymolysis sample mixed with the six nucleosides and IS; (C) a liver mRNA enzymolysis matrix sample from Epimedin C-treated mouse. 

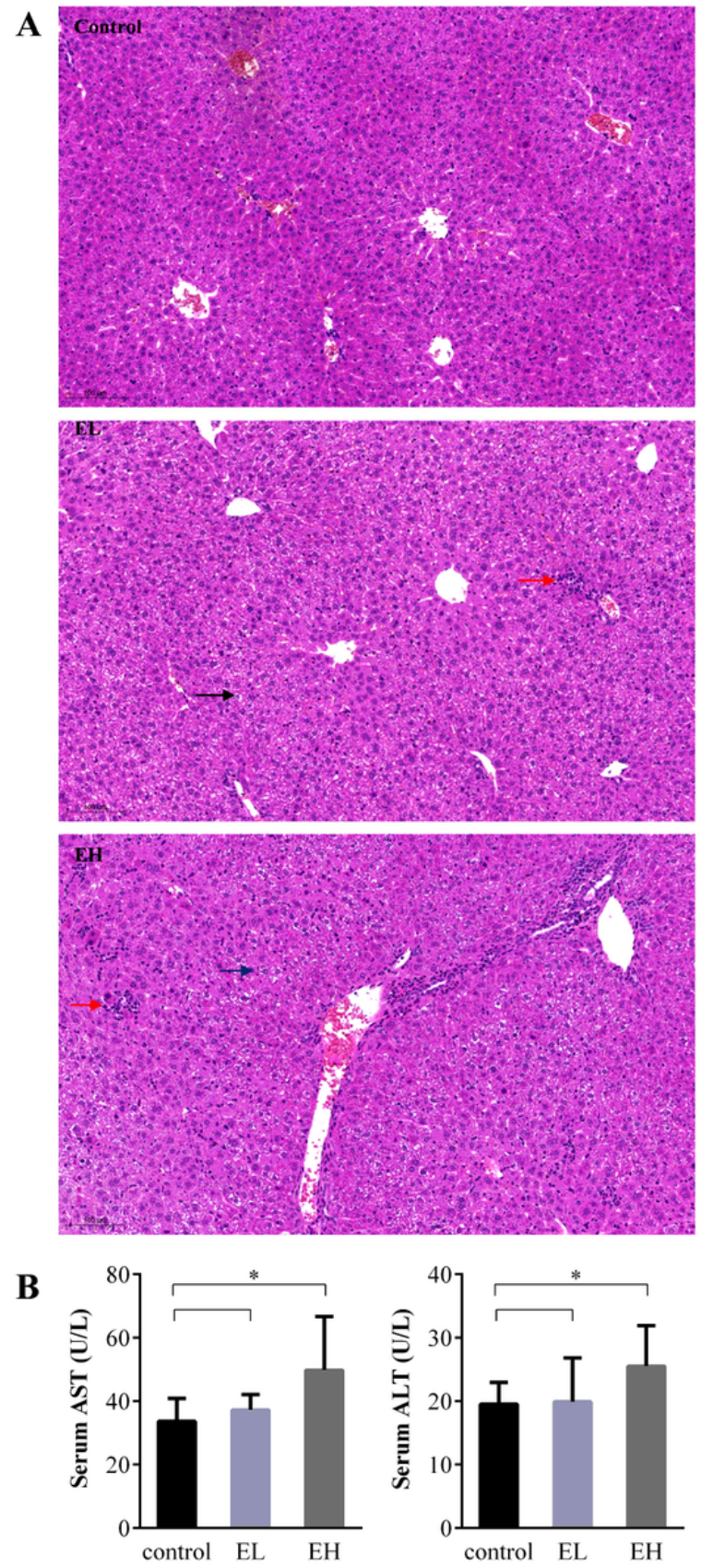

\section{Figure 3}

Representative photomicrographs (H\&E stain 100x magnification) of liver tissues (A) and serum aminotransferase levels (B) after Epimedin $\mathrm{C}$ challenge. Epimedin $\mathrm{C}$ was absent in the normal control group. The mice were treated with Epimedin $\mathrm{C}$ (10 $\mathrm{mg} / \mathrm{kg})$ in the EL group. The mice were treated with Epimedin $\mathrm{C}(40 \mathrm{mg} / \mathrm{kg})$ in the EH group. ${ }^{*}<0.05$ vs. the normal control group. The black arrow represents the vacuolar degeneration and the red arrow stands for the inflammatory cell infiltration. 

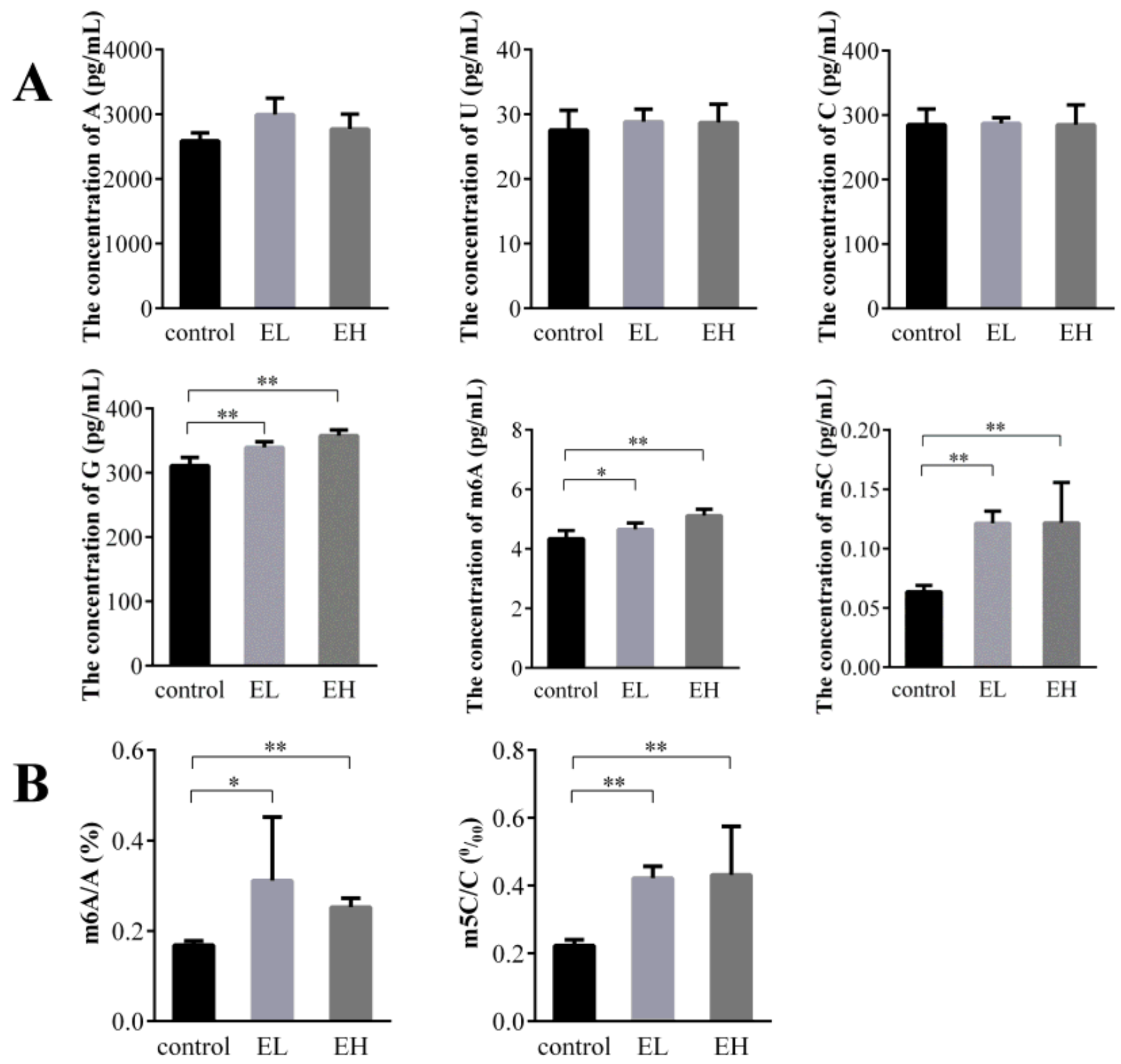

Figure 4

The concentration levels of six nucleosides and the relative contents of m6A and $\mathrm{m} 5 \mathrm{C}$ in test samples of the mice liver mRNA in the control and Epimedin C groups. (A) The concentration levels of $A, U, C, G, m 6 A$ and m5C in test samples; (B) the content of modified nucleoside m6A (ratio of $\mathrm{m} 6 \mathrm{~A} / \mathrm{A}$ ) and $\mathrm{m} 5 \mathrm{C}$ (ratio of $\mathrm{m} 5 \mathrm{C} / \mathrm{C}$ ). Epimedin $\mathrm{C}$ was absent in the normal control group. The mice were treated with Epimedin C (10 mg/ $\mathrm{kg})$ in the EL group. The mice were treated with Epimedin C $(40 \mathrm{mg} / \mathrm{kg})$ in the EH group. ${ }^{*} \mathrm{P}<0.05$ and ${ }^{*} \mathrm{P}<0.01$ vs. the normal control group. 